\title{
MENGUAK SASTRA DALAM SEJARAH ISLAM
}

\author{
Khaerunnisa $^{1)}$, Dini Septiana ${ }^{2}$ \\ Pendidikan Bahasa dan Sastra Indonesia \\ Fakultas Ilmu Pendidikan \\ Universitas Muhammadiyah Jakarta \\ Jalan KH. Ahmad Dahlan, Ciputat, Cirendeu, Jakarta Selatan 15419 \\ khaerunnisa@umj.ac.id
}

\begin{abstract}
ABSTRAK
Sejak dahulu sastra menjadi pendamping sejarah perjalanan Indonesia. Sastra menjadi salah satu wadah untuk mengisahkan setiap tragedi yang terjadi dalam perkembangan Indonesia. Sejarah perkembangan Islam seringkali dikisahkan dalam syair-syair. Kata sastra sangat akrab dalam kehidupan masyarakat. Sastra dapat memainkan perannya sebagai media yang menjadi sumber informasi untuk menyampaikan tentang nilai-nilai pendidikan moral dan membudayakan sebuah kisah kegenerasi selanjutnya. Oleh karena itu dalam pembahasan ini akan menguak sastra dan ajaran Islam serta menguak ajaran Islam dan sastra pada saat ini terkhusus di Indonesia. Karya sastra yang kental dengan budaya sering sekali diasumsikan tidak bisa dikaitkan denga agama, dalam pembahasan ini menguak sejarah Islam yang akrab dengan budaya. Metode yang digunakan dalam penelitian ini yaitu metode kualitatif. Penelitian ini menggunakan data yang berasal dari studi pustaka dan menyajikan hasilnya. Sastra sejak dulu sudah digandrungi sebagai alat penyampaian pesan dengan cara memainkan kata-kata sehingga indah dibaca dan didengar. Hasil penelitian ini dapat dipahami bahwa sastra sesungguhnya telah ada pada zaman penyebaran Islam yaitu sebelum Nabi Muhammad SAW mendapatkan wahyu yang dapat dibuktikan dari ayat dan kisahat sahabat pada masa itu. Hasil penelitian ini mengungkap sastra sebelum ajaran Islam dan unsur sastra yang terdapat pada kitab suci Alquran. Bangsa Arab pada masa penyebaran Islam memang telah mengenal sastra namun sering disebut pintar bermain kata. Pada masa itu jika seseorang pandai bermain kata indah maka mereka akan menjadi seseorang yang dihargai dan dianggap berintelektual, oleh karena itu manusia pada masa itu setelah Alquran diturunkan banyak yang mengagumi kata demi kata yang terdapat di dalamnya. Dalam penelitian ini terkuak bahwa benar Alquran mengandung nilai-nilai sastra.
\end{abstract}

Kata kunci: Sastra, Sejarah Islam, Pembelajaran dan Moral 


\section{PENDAHULUAN}

$\mathbf{K}$ arya sastra mempunyai peran yang sangat penting dalam sejarah Islam (Faruqi dalam Sunhaji, 2016: 1). Jika mengacu dalam ayat Alquran, saat itu Arab sedang masa kejayaan seni memperindah (memainkan) kata. Pada saat itu siapapun yang dapat atau mahir dalam memainkan kata menjadi indah maka akan dianggap "intelektual". Mereka berlomba untuk menciptakan karya yang paling terbaik. Oleh sebab itu, jika diperhatikan dengan seksama Alquran diturunkan dengan kata yang begitu kaya dengan keindahan dan etika melebihi karya sastra yang ada pada masa itu. Setiap karya sastra melukiskan berbagai permasalahan dalam kehidupan manusia dalam bermasyarat dan kepada sang pencipta. Sastra banyak yang mendefinisikan sebagi cerita fiksi atau hasil imajinasi pengarang, tetapi sebuah karya sastra jika dihayati dan memahami isi kandungan maka banyak pembelajaran di dalamnya. Beberapa ahli mendefinisikan bahwa saat ini sastra mengalami turun eksistensinya dikalangan masyarakat. Masyarakat mulai melupakan karya sastra, jika dipahami bahwasanya estetika dalam karya sastra adalah etika dan moral.

Sebagian cerita yang terdapat dalam sastra terdapat di dalam kisah sebuah gambaran kisah kehidupan atau pun romansa yang mengandung nilai-nilai moral serta ideologi kemanusiaan. Etika dan moral dalam sebuah karya sastra baik tentu akan memberikan wawasan serta pengetahuan dan ruhiyan sehingga pembaca dapat merasakan pembelajaran dalam karya sastra. Karya sastra juga jika dihayati dapat memberikan etika pada perkembangan prilaku pembaca. Oleh karena itu, penggiat sastra dan ahli pendidik meyakini bahwasanya etika moral dan keindahan merupakan nilai estetika dalam sebuah karya sastra.

Agama dan sastra merupakan dua bagian yang dapat dikatakan saling berhubungan. Dalam ajaran agama Islam terdapat nilai pembelajaran yang dapat diambil dan dihayati dalam masyarakat. Oleh karena itu, pada tulisan ilmiah ini akan menguak hubungan antara sastra dan ajaran agama serta mengulas kisah-kisah dalam Alquran yang mengandung keindahan dan pesan moral yang identik pada karya sastra. Dalam pembahan kali ini penulis berusaha mengungkap mengenai peran karya sastra perannya dalam tradisi dan budaya pendidikan Islam baik secara langsung maupun tidak. Dengan ini, penulis berpendapat bahwa kaum muslimin harus memahami dan mempelajari karya sastra sebagai kegiatan memahami sisi kehidupan dan dari sisi ketuhanan. Oleh karena itu, tulisan ini akan diperkuat dengan menelusuri penafsiran sejarah yang ada selama ini dari aspek tekstual dan memahami unsur sastra yang terkandung dalam Alquran.

\section{METODE PENELITIAN}

$\mathrm{M}$ etode kualitatif digunakan dalam penelitian ini, yaitu dengan menganalisis data yang telah didapatkan. Data dikumpulkan dengan teknik purposive sampling. Selain itu, penulis melibatkan orang lain yang dapat membantu memahami fenomena. Data yang didapatkan merupakan dari studi pustaka kemudian diolah untuk mengupas data yang didapatkan dengan cara menggunakan kontekstual. Data yang didapatkan berupa sejarah Islam dan kisah yang terkandung dalam Alquran. Data tersebut yang menjadi dasar dalam tulisan ilmiah ini. Kontekstual dalam tulisan ini yaitu dengan membedah sesuatu berdasarkan konteks yang ada untuk mendapatkan hasil yang sesuai dengan $30 \mid$ Pena Literasi 
tujuan penelitian. Penulis menggunakan teknik kontekstual sebagai analisis data. Teknik itu merupakan sebuah pisau yang baik untuk mengupas sejarah Islam dengan sastra. Meneliti sesuai konteks kemudian dapat mengulas keterkaitan sejarah Islam dan Alquran dengan sastra. Data yang telah diolah menjadi hasil kemudian disajikan dengan cara mendeskripsikan hasil yang telah didapat.

\section{HASIL PENELITIAN}

\section{Sastra dan Moralitas Sastra}

Dalam kehidupan

bermasyarakan dan kebangsaan tidak dapat terpisahkan oleh sastra. Dahulu sasatra digunakan Dalam ritual-ritual tertentu, sebagai alat untuk menceritakan cerita dan sebagai komunikasi saat itu. Pusat Bahasa menjelaskan (2003: 159) Sastra adalah karya tulis yang jika dibandingkan dengan karya tulisan lain memiliki ciri keunggulan seperti keorisinilan, keartistikan, serta keindahan dalam isi ungkapan. Jika dilihat definisi dari Kamus Besar Bahasa Indonesia V (KBBI V) bahwa sastra adalah bahasa kata-kata, gaya bahasa yang dipakai dalam kitab-kitab atau kisah. Sastra dapat berarti sebuah karya berupa tulisan indah yang mencari alat komunikasi penyampaian kisah dan nilai-nilai. Dapat dipahami bahwa sastra adalah sebbuah karya yang bersifat fiksi atau nonfiksi yang ditulis oleh pengarang untuk menyampaikan informasi.

Karya sastra identik dengan estetika, karena sastra dapat diartikan sebagain ungkapan sebuah pemikiran dan perasaan yang kemudian diapresiasikan yang disakin dalam bentuk yang berbeda-beda. Saat ini sastra menjadi sebuah topik pembicaraan yang sering diangkat oleh para ahli, dimana sastra menjadi sebuah alat yang baik untuk membantu dunia pendidikan dalam proses pembelajaran moral dan etika. Jika dilihat dari siswa saat ini disaat era perkembangan teknologi yang semakin melesat menimbulkan kemerosotan moral dan nilai luhur, oleh karena itu sastra sangat dibutuhkan untuk wadah kreatifitas siswa dan pendidikan karakter serta menjadi sebuah pembelajaran.

Dari pengertian sastra di atas dapat dipahami bahwa sastra adalah seluruh aspek yang ada pada kehidupan yang kemudian dihasilakan dari pemikiran yang munjul berasal dari pengalam jiwa. Karya sastra dapat dipahami sesuai dengan bagaimana pembaca mengasumsikan sebuah karya sastra. Oleh sebab itu dalam sebuah karya sastra tidak ada karya yang baik dan buruk atau benar atau tidak, jika dipahami sebuah sastra yang dihasilkan sesuai dengan gaya penulisan pengarang itu sendiri. Oleh karena itu, karya sastra memiliki nilai yang sangat tinggi karena dari sebuah tulisan dapet menimbulkan emosi dari pembaca serta tidak sembarang orang memiliki kemampuan menuangkan sebuah cerita dalam sebuah karya.

Dalam mempelajari tentang moralitas dalam sebuah sastra sangat berlimpah, moralitas sastra biasanya ditransfer kepada pembaca secara langsung maupun tidak langsung. Penggabaran pengarang terhadap alur cerita sebuah cerita yang berawal dari pengenalan cerita beranjak kepada penyajian konflik hingga sampai pada penyesaian, kemudian memberikan kesadaran pemikiran terhap pembaca 
sehingga dapat menilai mana prilaku baik dengan tidak dalam sebuah karya.

Keberadaan sastra Islam sangat menarik. Sastra Islam dapat dipahami seluruh aspek Dalam kehidupan yang bersumber dari jiwa yang penuh dengan keimanan dan diselesaikan dengan keimanan. kemudian diungkap dengan cara yang luas, misalnya dalam mengungkap manusia dengan dengan tuhan atau aturan kehidupan. Hubungan kebaikan dan ketidak baikan bahwa menungkap tentangan hubungan dengan manusia dengan manusia. Kemudian mengulas berpakaian dan cinta yang dijelaskan sangat luas dan mendalam. Islam sendiri mempertimbangkan sisi ketuhanan sebagai sesuatu yang sangat erat dengan keindahan, mengambarkan kehidupan yang berupa aturan.

\section{Sastra dalam Ajaran Islam}

Sejak dahulu dalam masyarakat peradaban dimasa Islam baru disebarkan seni mengolah kata menjadi indah sangat termasyur pada masa itu. Seperti yang dikemukakan al-Faruqi dalam Sunhaji (2015: 48) menjelaskan hubungan antara sastra dengan Islam seperti dalam isi Alquran telah memberikan inspirasi banyak pemikir, seniman maupun ulama pada masa itu untuk menulis kitab dan karya sastra. Pada dasarnya estetika dan pesan yang ada di dalam sebuah karya sastrawan Islam yang telah membuka pemikiran dan hati untuk menjadikan Allah SWT sebagai yang paling pantas untuk diyakini. Sastrawan Islam selalu mejadikan Allah yang tertinggi dalam setiap karangannya, dengan pembawaan emosional, pembaca akan terhanyut pada penemuan esensi kehidupan dari sebuah karya sastra.

Keindahan bahasa Alquran tidak dapat diragukan lagi. Alquran juga mengandung banyak kisah dimana memiliki unsur sastra didalamnya. Tradisi dalam pendidikan Islam sastra pun memiliki peran penting dalam memberikan pesan dan nilai-nilai. Ajaran tentang jati diri, pengetahuan, hubungan manusia dengan alam semesta serta hubungan dengan Tuhan, sering sekali termanifestasi dalam teks sastra yang nantinya akan dibaca oleh masyarakat secara luas. Berdasarkan pada ranah kesejarahan, filsafat, dan dimensi kehidupan dari umat Islam yang tidak dapat terlepas dari lingkup keindahan al-Qur'an dan Hadis, oleh karena itu sangat menarik untuk menilik pada peranan sastra dalam tradisi pendidikan Islam serta sastra yang terdapat dalam Islam. Jika dilihat dalam sejarah Suanan boning dalam berdakwah menggunakan sentuhan batin.

Islam selalu mendasarkan pengetahuan kepada konsep kehidupan, ketakutan orang Islam pada masa menjelang kenabian terakhir yaitu Muhammad SAW. Alquran diturunkan kepada nabi menggunakan estetika yang sangat bagus dan mengalami ketenaran di bangsa Arab. Adanya Alquran membuktikan bahwa alquran adalah sebuah kebesaran Allah tidak ada mahluk apapun yang dapat meniru kata demi kata, kalimat demi kalimat dalam sebuah karya sastra. Hubungan antara Alquran dan sastra setidaknya terdapat dalam tiga hal. Pertama, berhubungan dengan pandangan estetika, hubungan karya sastra dengan keindahan dengan ruang akidah. Kedua, pembelajaran yang mengarah kepada etika dalam konteks 
sosial. Ketiga, berkenaan dengan ekspresif dalam konteks syariah.

Jika ditelisik dengan saksama bahwasannya dalam Alquran banyak kisah yang terkandung didalamnya seperti cerita kisah para nabi, kisah sahabat dan kisah hari akhir. kisahkisah yang terdapat dalam Alquran benar adanya dan perlu diyakini namun, kaitannya dengan sastra dapat dilihat dari keindahan bahasa yang digunakan, dapat dikatakan bahasa dalam kisah yang terdapat di Alquran adalah sastra tingkat tinggi tidak akan ada seorangpun yang dapat meniru kata demi katanya. Kisah-kisah yang tercatat dalam alquran jika diamati terdapatat unsur sastra dimana didalamnya terdapat prolog, konflik dan epilog. Jika dianalisis maka dari kisah yang berada dalam alquran memiliki unsur intrinsic sebagaimana karya sastra.

Dalam Alquran ada teknik dalam memilah kisah; Pertama, sajian kesimpulan. Kesimpula adalah pemaparan inti cerita dari kesimpulan sampai rinciannya, seperti dalam surat Yusuf dimana sebuah kisah pertama kali nabi Yususf mengetahui bahwa beliau adalah nabi Allah. kisah tersebut pada ayat (6-7) yang menyampaikan benang merah cerita yaitu tuhan memberitahu kenabian Yusuf lalu mengajarinya dan memberikan nikmat pada keluarganya dan keluarga Yuqub sebagaimana kakeknya bahwa Allah yang maha mengetahui. kisah tersebut adalah benang merah atau simpulan dari kisan Yusuf yang menjadi pembuka dalam cerita. Setelah itu dilajutkan kisah yaitu pada ayat (8-9) tahap ini dalam sastra disebut dengan orientasi yaitu dengan memeperkenalkan
Yusuf dengan saudaranya hingga Yusuf menjadi dibenci oleh saudaranya karena iri padanya. Dilanjutkan dengan surat (21101) kisah ini dimana Yusuf di Mesir mulai lah konflik memuncak saat Yusuf di penjara, timbul sebuah penyelesaian yaitu Yusuf menjadi orang kepercayaan raja dan kemudian bertemu dengan saudaranya. Ayat tersebut jika dilihat dari sudut pandang sastra sangat terstruktur berawal dari orientasi konflik, komplikasi hingga penyelesaian. Penggunaan bahasa pun sangat menarik dan sangat indah dibaca, kelebihan dari kata-kata dalam Alquran tidak ada yang dapat menirut seperti demikian.

Serupa dengan format pada Q.S Yusuf, Pada surat Al Kahfi juga menisahkan beberapa pemuda dalam gua, dalam cerita diawali dengan benang merah atau simpulan mengisahkan segerombolan pemuda di dalam gua, cerita tersebut merupakan sebuah ringkasan dari cerita. Kemudian dilanjutkan dengan penceritaan mengapa mereka masuk ke dalam gua, keadaan mereka di dalam gua, ketika mereka bangun dari tidur, sampai kepada sikap penduduk dan perselisihan pendudukan kota tentapemuda-pemuda tersebut, tertera pada ayat $14-22$.

Kemudian pada kisah Firaun dan surah Al- Qashas, dalam Alquran menceritakan kisah tersebut bermula pada adegan klimaks. dengan cara mengisahkan ceritanya dari awal sampi akhir. klimaks tersebut ada dengan menceritakan keganasan Firaun. Ayat tersebut mengisahkan kejahatan dana pa saja yang dilakukan oleh Firaun sehingga mengfirmankan bahawa Firaun adalah termasuk orang-orang yang berbuat kerusakan (Q.S al-Qashas:3-5). 
Demikianlah kisah nabi Musa mulai diceritakan saat Musa dilahirkan dan dibesarkan sampai ia dewasa. kemudia Musa meninggalkan Mesir bertemulah denga dua anak perempuan kemudian ia mendapatkan wahyu untuk menyeru kepada Firaun sampai kepada Musa mendapat Wahyu kitab Taurat ayat 7-43. Kisah tersebut memiliki alur dan tata cara penyajian yang sangat apik jika dilihat dari estetika penyajian sastra. Dapat disimpulkan bahwa dalam perkembangan Islam dan sastra sangat erat kaitannya semenjak peradaban Islam bermain katakata indah merupakan hal yang sedang digandrungi pada masa itu.

\section{Pengisahan kisah sejarah} Islam dan kisah nabi serta sahabat yang tertera dalam Alquran dapat dijadikan pembelajaran dalam kehidupan sebagaimana fungsi Alquran yaitu sebagai pedoman dalam hidup di dunia serta di akhirat. kisah yang tertera dalam Alquran diantaranya kisah nabi Adam, kisah nabi Isha dengan ibundanya, kisan nabi Luth, Nuh, dan masih banyak lagi. Sering sekali kisah-kisah tersebut dijadikan pembelajaran dalam kehidupan bermasyarakat dapat menjadi teguran terhadap kisah lalu untuk bercermin diri. Bangsa Arab sudah sangat akrab dengan syair-syair sayair merupakan bagian dari sebuah karya sastra. Syair kerapkali digunakan sebagi media untuk menyebarkan agama Islam dan sebuah cerita pelipurlara pada masa itu. Penjelasan diatas adalah bagaimana kisah-kisah yang berada dalam Alquran memiliki unsur sastra didalamnya. Banyak sekali kisah yang berada dalam Alquran kisah nabi, kisah sahabat, kisah kebenaran Islam, kisan manusia terdahulu, kisah kaum kafir dan kisah manusia kelak antara kehudupan setelah meninggal.

\section{Pengaruh Sastra Dalam Kehidupan dan Perkembangan Indonesia}

Bangsa Indonesia sebelum masa kemerdekaan sudah mengenal sastra, pada masa itu untuk mengabari suatu keadaan dengan menulis surat, buku atau menyiarkan radio. Tulisan pada masa itu memang memjadi wadah penyampai pesan terlebih pada masa itu bahasa Indonesia masih belum diresmikan sehinggan banyak masyarakat menulis dengan bahasa melayu dan menggunakan pengunaan kata yang yang begitu indah. Pada masa penyebaran Islam, Islam sampai di Indonesia dari perdagangan dan pernikahan. Pada masa itu saudagar menyair-nyairkan ajaran Islam. Sering detemukan buku lama dengan menyairkan ajaran Islam dengan sangat indah dan terdapat njilai-nilai di dalamnya.

Indonesia masa itu menuliskan dalam setiap buku dengan gambaran peristiwa yang terjadi. Pada masa Balai Pustaka banyak sekali tulisan dari pemuda, penulis yang dimuat dalam koran atau buku, dimana tulisan tersebut meningkatkan gairah untuk melawan ketidak adilan dan penjajahan pada masa itu. Saat itu pemuda Indonesia selalu menunggu instruksi dan kobaran semangat dari tulisan baru lah pemuda turun dan ikut andil turun memperjuangkan tanah air. Dapat dipahami bahwasanya yang mengantarkan Indonesia kepada 
gerbang kemerdekaan, sastra ikut andil di dalamnya. seperti dalam buku Soe Hok Gie menceritakan setelah merdeka ternyata Indonesia masih belum merdeka banyak pencuri berdasi dana mahasiswa yang harusnya garda terdepan justru tergiur dengan mobilmobil mewah yang diberika sehingga bungkam seribu bahasa. buku tersebut memberi kesadaran untuk pemuda merdeka dan memperjuangkan hak masyarakat. Setelah masa menjelang kemerdekan dan setelahnya contoh yaitu novel bumi manusia karya Pramoedya Ananta Toer, hasil karya Soe Hok Gie, dan Buya Hamka.

\section{KESIMPULAN}

$O$ astra dapat menjadi media dalam pembelajaran saat ini di era kemajuan teknologi. Sastra merupakan cara jitu yang dapat diterapkan dalam pendidikan agara siswa memahami nilai luhur yang terdapat di dalamnya. Moral dari segi ketuhanan dan sosial banyak terkandung didalam sastra. Pendidikan moral saat ini memang sangat penting di era kemajuan teknologi saat ini. Dengan adanya sastra seakan membawa angin segar kepada pembaca dimana sastra memiliki nilai yang jika dibaca mendapatkan pembelajaran. Sastra memang hal yang menarik intuk didalami, Islam memiliki kitab yang sangat indah dalam ajarannya tak dapat seorangpun dapat membuat tulisan dengan seindah tersebut dan kisah bangsa Arab sebelum Islam disebarkan sangat menarik dengan kaitannya dengan sastra. Setelah dipahami bahwa di dalam Alquran banyak mengandung kisah dan unsur dari sastra. Bahkan sastra telah dikenal sebelum kenabian Muhammad SAW. Dari setiap ayat dalam Alquran mengandung unsur sastra luar biasa.

\section{REFERENSI}

Asriyah. Perkembangan Sejarah Sastra Arab. Rihlah: Jurnal Sejarah dan Kebudayaan.. Vol. V. No. 2/2016

Creswell, J. W. 2016. Research Design: Pendekatan Kualitatif, Kuantitatif, dan Mixed. Yogyakarta: Pustaka Pelajar.

Sukardi, Imam dkk. 2003. Pilar Islam: Bagi Pluralisme Modern. Solo: Tiga Serangkai

Suhanji. 2016. Sastra Dalam Tradisi Pendidikan Islam. Ibda: Jurnal Kebudayaan Islam. Vol. 13, No. 1, Januari-Juni 2015

Susanto. A. 2010. Pemikiran Pendidikan Islam. Jakarta: Amzah.

Syi'aruddin, Anwar Muhammad. 2016. Transformasi Nilai-nilai Islam Dalam Karya Sastra. Prosiding Seminar Nasional Bahasa dan Sastra "Bahasa, Sastra, dan Politik di Era Siber". Program Studi Sastra Indonesia Universitas Pamulang

Sukardi, Imam dkk. 2003. Pilar Islam: Bagi Pluralisme Modern. Solo: Tiga Serangkai 